\title{
Growth and quality of Handroanthus heptaphyllus (Vell.) Mattos. seedlings as a function of controlled release fertilizer doses
}

\author{
Adrielly Costa Souza \\ Graduating in Forest Engineering from the Federal Rural University of the Amazon - UFRA \\ $\bowtie$ costasouzaadrielly@gmail.com \\ Dênmora Gomes de Araújo \\ Doctor Professor at the Federal Rural University of the Amazon - UFRA \\ Gabriel Pinheiro Silva \\ Graduating in Agronomy from the Federal Rural University of the Amazon - UFRA \\ Jéssy Anni Vilhena Senado \\ Graduate student at the Luiz de Queiroz School of Agriculture - ESALQ / USP \\ Marcos André Piedade Gama \\ Doctor Professor at the Federal Rural University of the Amazon - UFRA
}

Recebido em 20 de fevereiro de 2020

Aceito em 2 de julho de 2020

\begin{abstract}
:
Controlled-release fertilizers are great allies in the production of seedlings. However, there is a lack of studies focusing on the use of these fertilizers in native forest species. This study aimed to evaluate the effect of different doses of controlled release fertilizers (CRF) on the development and quality of seedlings of Handroanthus heptaphyllus (Vell.) Mattos. The experiment was carried out under greenhouse conditions with plastic cover for a period of 150 days. The pots were distributed in randomized blocks, using twenty plants per experimental unit. The treatments consisted of four doses of CFR Osmocote ${ }^{\circ}\left(0,4.1,8.2\right.$ and $\left.12.3 \mathrm{~g} \mathrm{dm}^{-3}\right)$ in the formulation NPK 15-09-12, with four replications. The following variables were evaluated: seedling height $(\mathrm{H})$, stem diameter (SD), root length (RL), number of leaf pairs (NLP), leaf area (LA), shoot dry mass (SDM), root dry mass (RDM), total dry mass (TDM), H/SD ratio, Dickson's quality index (DQI) and relative chlorophyll content (SPAD). All evaluated parameters responded significantly to the increasing doses of the CRF. The best responses were found for the doses between 8.5 to $9.5 \mathrm{~g} \mathrm{dm}^{-3}$, considering the evaluated experimental conditions. Keywords: Osmocote ${ }^{\circ}$, nursery fertilization, forest seedlings.
\end{abstract}

\section{Crescimento e qualidade de mudas de Handroanthus heptaphyllus (Vell.) Mattos. em função de fertilizante de liberação controlada}

\begin{abstract}
Resumo:
Na produção de mudas os fertilizantes de liberação controlada são grandes aliados, no entanto, poucos estudos são realizados quanto a utilização destes fertilizantes em espécies florestais nativas. 0 objetivo deste trabalho foi avaliar o efeito de diferentes doses de fertilizantes de liberação controlada (FLC) no desenvolvimento e qualidade de mudas de Handroanthus heptaphyllus (Vell.) Mattos. 0
\end{abstract}


experimento foi conduzido em casa de vegetação com cobertura de plástico por um período de 150 dias. O delineamento experimental adotado foi em blocos casualizados, com quatro tratamentos e quatro repetições, utilizando-se vinte plantas por unidade experimental. Os tratamentos foram compostos por quatro doses de FLC Osmocote ${ }^{\circledast}(0 ; 4,1 ; 8,2$ e $12,3 \mathrm{~g} \mathrm{dm}-3)$ na formulação NPK 15-0912. As variáveis avaliadas foram: altura da muda (H), diâmetro do coleto (DC), comprimento da raiz (CR), número de pares de folhas (NPF), área foliar (AF), massa seca da parte área (MSPA), massa seca da raiz (MSR), massa seca total (MST), relação H/DC, índice de qualidade de Dickson (IQD) e teor relativo de clorofila (SPAD). Todos os parâmetros avaliados responderam significativamente as doses crescentes do FLC. As melhores respostas foram com as doses do FLC entre 8,5 a 9,5 g dm -3 dentro das condições experimentais avaliadas.

Palavras-chave: Osmocote ${ }^{\circ}$, adubação em viveiros, fertilização, mudas florestais.

\section{Crecimiento y calidad de las plántulas de Handroanthus heptaphyllus (Vell.) Mattos. en la función de fertilización de liberación controlada}

\section{Resumen:}

En la producción de plántulas, los fertilizantes de liberación controlada son grandes aliados, sin embargo, se realizan pocos estudios sobre el uso de estos fertilizantes en especies nativas de bosques nativos. El objetivo de este trabajo fue evaluar el efecto de diferentes dosis de fertilizantes de liberación controlada (FLC) en el desarrollo y la calidad de las plántulas de Handroanthus heptaphyllus (Vell.) Mattos. El experimento se realizó en un invernadero con 50\% de sombra durante un período de 150 días. El diseño experimental adoptado fue en bloques al azar, con cuatro tratamientos y cuatro repeticiones, utilizando veinte plantas por unidad experimental. Los tratamientos fueron cuatro dosis de Osmocote ${ }^{\circledast}$ FLC $\left(0 ; 4.1 ; 8.2\right.$ y $\left.12.3 \mathrm{~g} \mathrm{dm}^{-3}\right)$ en la formulación NPK 15-09-12. Las variables evaluadas fueron: altura de la plántula $(\mathrm{H})$, diámetro del tallo (DC), longitud de la raíz (CR), número de pares de hojas (NPF), área de la hoja (AF), masa seca del área (MSPA), masa seca de raíz (MSR), masa seca total (MST), relación H / DC, índice de calidad de Dickson (IQD) y contenido relativo de clorofila (SPAD). Todos los parámetros evaluados respondieron significativamente. Fue posible observar que, para todas las variables estudiadas, se obtuvieron los mejores promedios con dosis entre 8.5 a $9.5 \mathrm{~g} \mathrm{dm}^{-3}$ dentro de las condiciones experimentales evaluadas.

Palabras clave: Osmocote , fertilización en viveros, fertilización, plántulas forestales.

\section{INTRODUCTION}

Handroanthus heptaphyllus (Vell.) Mattos, commonly referred to as the pink trumpet tree (or "Ipê Rosa" in Portuguese), is a Bignoniaceae tree native to tropical regions with phytogeographic distribution in the Brazilian Cerrado and the Atlantic Forest. The wood is hard and heavy, showing excellent quality for various purposes and resistant to fungi attacks. In addition, it has medicinal and ornamental characteristics, besides being considered decorative (TRESENA, 2009).

The pink trumpet tree is an arboreal species, deciduous, reaching up to $30 \mathrm{~m}$ in height and $100 \mathrm{~cm}$ in diameter. It is often found in areas of native vegetation in Brazil and other Latin American countries, such as Argentina, southern Bolivia, eastern Paraguay and 
Uruguay, in environments with rainfall ranging from $1000 \mathrm{~mm}$ to $1900 \mathrm{~mm}$ annually and temperatures ranging from 18 to $26^{\circ} \mathrm{C}$ (CARVALHO, 1994).

This species has great potential to be used in reforestation and as part of revegetation in the recovery of degraded areas. Although it presents great potential for exploration, there have been few studies regarding the species, especially when compared with the genus Pinus and Eucalyptus. Moreover, research on the production of native seedlings is still scarce, mainly regarding the germination potential, development of native tree seedlings and the composition of the substrate for the production of seedlings (OLIVEIRA et al., 2016; ZAMITH and SCARANO, 2004). This information is directly related to the quality of seedlings, which will interfere with growth and adaptability in the field (GARCIA; SOUZA, 2015). Among these factors, substrate fertility or substrate base fertilization is a relevant factor for the growth of more resistant plants.

The use of fertilizers in seedling production is a determining factor for quality and survival in the field. Thus, a substrate rich in nutrients can contribute to an optimal development of the plant in the field (CECONI et al. 2007; CRUZ et al., 2006). According to Dutra et al. (2016), conventional fertilizers allow a large supply of nutrients for the plant. However, it provides nutrient losses to the environment through leaching, requiring nutritional replacement and higher production costs.

Therefore, the use of controlled-release fertilizers (CRF), such as Osmocote, is an alternative to minimize the risk of damage to plants. Those fertilizers potentially provide continuous availability of nutrients with no splited application, decreasing operating costs and losses by leaching (MENDONÇA et al., 2008). For example, in Pias et al. (2015), when testing the production of seedlings according to the types of container and sources of fertilizer, found that the seedlings produced in tubes with doses of the CRF Osmocote ${ }^{\circledR}$ showed the highest increments in height and diameter when compared with the other fertilizer sources. Silva et al (2019), showed the influence of Osmocote ${ }^{\circledR}$ in the nursery seedling phase of Inga heterophylla Willd.

Therefore, this study aimed to evaluate the effect of different doses of controlled release fertilizers on the development and quality of Handroanthus heptaphyllus (Vell.) Mattos. seedlings, cultivated in nurseries. 


\section{METHODOLOGY}

The experiment was conducted during 150 days under greenhouse conditions with plastic and lateral coverage with 50\% shade, in the Federal Rural University of the Amazon UFRA, located in Belém, state of Pará, Brazil (1²7'12.6" S, 48²6'33.5" W).

Seedlings of Handroanthus heptaphyllus (Vell.) Mattos, obtained from the germination of seeds, were transplanted into tubes of $280 \mathrm{~mL}$ filled with substrate formed by Tropstrato + vermiculite, in the ratio $1: 1$, to which the controlled-release fertilizer Osmocote was manually mixed at different doses.

The experiment followed a randomized block design with four treatments and four replications, using 14 plants per plot. The treatments consisted of four doses $(0,4.10,8.2$ and $12.3 \mathrm{~g} \mathrm{dm}^{-3}$ ) of Osmocote ${ }^{\circ}$. This fertilizer has a NPK of 15-09-12 formulation, plus $1.3 \% \mathrm{Mg}, 5.9 \%$ S, $0.02 \% \mathrm{~B}, 0.05 \% \mathrm{Cu}, 0.46 \% \mathrm{Fe}, 0.06 \% \mathrm{Mn}, 0.02 \% \mathrm{Mo}$ and $0.05 \% \mathrm{Zn}$, with nutrient availability time of approximately 5 to 6 months.

During the greenhouse phase, the treatments in the seedlings consisted of irrigation twice a day and manual control of pests and diseases, when necessary. After 60 days of transplanting, the following parameters were evaluated: seedling height $(\mathrm{H})$, using a ruler graduated in centimeters from the soil surface to the tip of the apical bud; stem diameter (SD), using a digital caliper near the soil surface; root length (RL), after removing the seedlings from the nurseries, using a ruler graduated in centimeters, the length of the pivoting root was measured; and number of leaf pairs (NLP).

After measuring the parameters, 35 plants were collected from each treatment to obtain the leaf area (LA; in $\mathrm{cm}^{2}$ ), using a leaf area reader (model LI-3100C). In addition, shoot dry mass (SDM), in g plant ${ }^{-1}$, root dry mass (RDM), in g plant ${ }^{-1}$, and total dry mass (TDM), in g plant $^{-1}$, were obtained, which were determined after drying in an oven with forced air circulation at $60^{\circ} \mathrm{C}$ until constant weight. The data of the relative chlorophyll content (SPAD) were determined using a chlorophyll meter (model Minolta SPAD-502). After obtaining the parameters, the H/SD ratio and the Dickson's quality index (DQI) of the seedlings were determined, according to the recommendations of Dickson et al. (1960), using the following formula: 


$$
D Q I=\frac{\mathrm{TDM}(\mathrm{g})}{\frac{H(\mathrm{~cm})}{S D(\mathrm{~mm})}+\frac{S D M(\mathrm{~g})}{R D M(\mathrm{~g})}}
$$

The results were submitted to normality analysis using the Shapiro-Wilk test and the homogeneity of the data was assessed by the Levene test at 5\% probability, using InfoStat software (DI RIENZO et al., 2014). Analysis of variance was performed at 5\% probability by the F test. The effects of the doses of Osmocote were analyzed by regression equations, according to the methodology recommended by Banzatto and Kronka (1995), in which the maximum technical efficiency doses (MTED) were obtained from the derivation of the equations.

\section{DISCUSSION}

There was a positive influence of the controlled release fertilizer on the growth of the plants in relation to the control (treatment without use of fertilizer - T0). Seedlings heights varied according to the dose of Osmocote ${ }^{\circ}$, presenting a quadratic behavior. The maximum technical efficiency dose (MTED) was estimated at $8.2 \mathrm{~g} \mathrm{dm}^{-3}$ of fertilizer, corresponding to a height of $22.87 \mathrm{~cm}$ (Figure 1), which represented an increase of nearly $40 \%$ when compared with the control treatment. Rossa et al. (2011), when studying Araucaria angustifolia (Bert.) 0 . Ktze. and Ocotea odorifera (Vellozo) Rohwer seedlings, found that the best doses for this characteristic were $9 \mathrm{~kg} \mathrm{~m}^{-3}$ and 6 to $9 \mathrm{~kg} \mathrm{~m}^{-3}$ of Basacote ${ }^{\circledast} \mathrm{CRF}$, respectively. Mendonça et al. (2008), when studying Tamarindus indica L., estimated lower doses for this same variable, with the best dose of Osmocote ${ }^{\circ}$ being $5.2 \mathrm{~kg} \mathrm{~m}^{-3}$. These results indicate that there are differences in responses depending on the studied species and the type of controlled release fertilizer.

As for the stem diameter, the response to the doses of Osmocote followed the quadratic model, with MTED estimated at $8.8 \mathrm{~g} \mathrm{dm}^{-3}$, with an approximate SD of $6.6 \mathrm{~mm}$ (Figure 1), which was 56\% higher than the control treatment. For Gomes (2011), the analysis of the stem is an important strategy to determine survival of the seedlings after field application. In other studies with controlled release fertilizers, greater increases in stem diameter were also observed for species such as Anadenanthera peregrina (L.) Speg., Schinus 
terebinthifolius Raddi, Mimosa scabrella Benth, Peltophorum dubium (Spreng.) Taub.) and Aspidosperma parvifolium A. DC. (Rosssa et al., 2015; Stupp et al., 2015; Dutra et al., 2016; Menegatti et al., 2017).

The use of the CRF also provided a quadratic effect on the number of leaves per seedling, with MTED estimated at $8.4 \mathrm{~g} \mathrm{dm}^{-3}$, resulting in approximately nine pairs of leaves per seedling (Figure 1 ) at 60 days.

Figure 1: Height (H), stem diameter (SD) and number of leaves (NLP) of Handroanthus heptaphyllus (Vell.) Mattos seedlings as a function of controlled release fertilizer (Osmocote) doses at 60 days after germination.
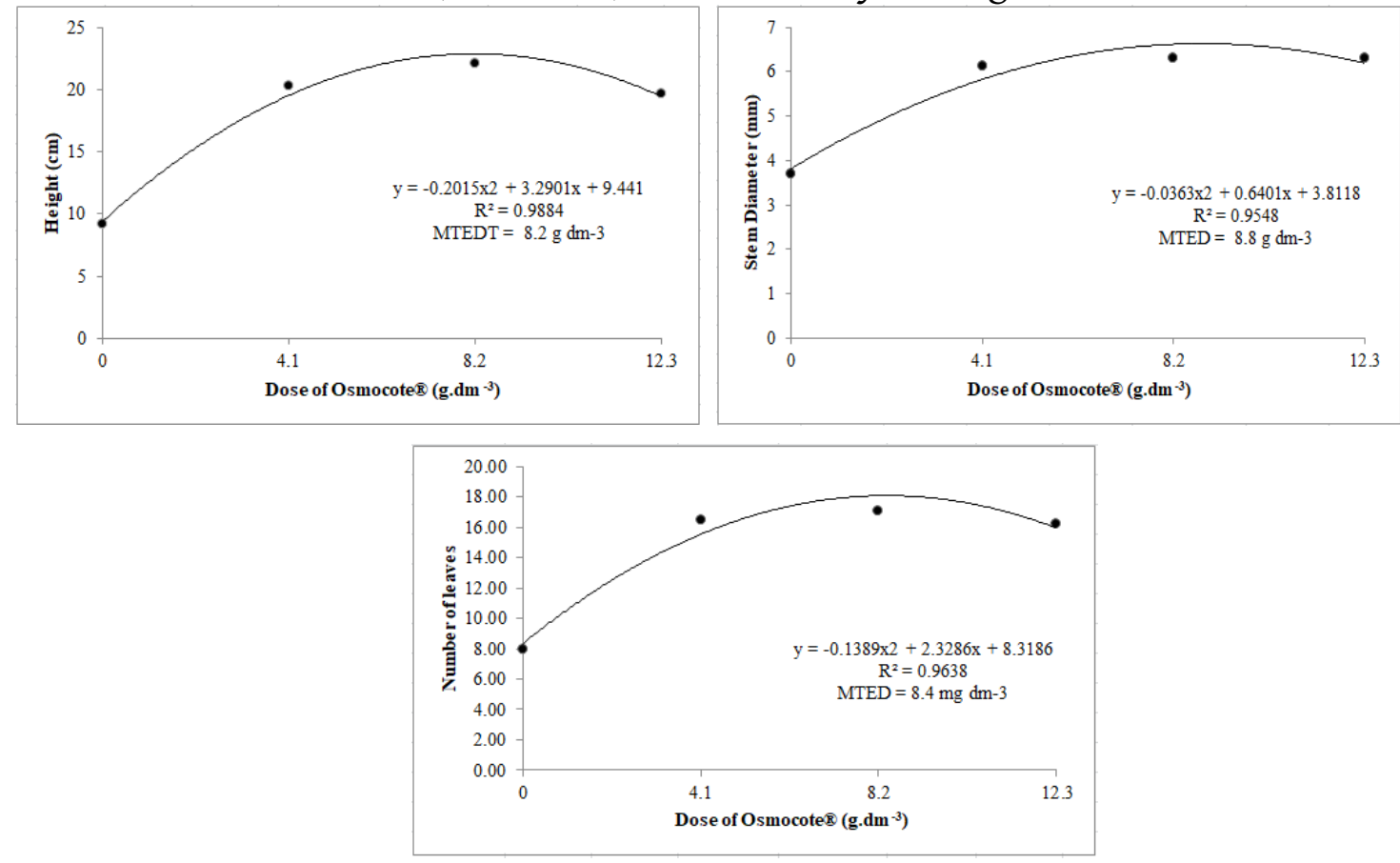

Source: Authors, 2019.

The result for leaf area indicated that the difference between the MTED value, which was $8.6 \mathrm{~g} \mathrm{dm}^{-3}$ (Figure 2), and, value obtained in the treatment without CRF was approximately $1622 \%$. Monteiro et al. (2005) stated that leaf area is an excellent indicator for investigating ecological adaptation, management effect, as well as estimating the productivity of a plant ecosystem, its growth and leaf development. 
The number of leaves and leaf area are essential for the survival of the species, since they influence the photosynthetic capacity and, consequently, the productivity of the plant. A recent study showed that Aspidosperma parvifolium A. DC. responded significantly to Osmocote, when considering the number of leaves and leaf area, obtaining MTED at 5.14 and $5.46 \mathrm{~g} \mathrm{dm}^{-3}$, respectively (MENEGATTI et al., 2017).

The chlorophyll content (Figure 2) increased with the increase in the doses of Osmocote, with MTED estimated at $9.4 \mathrm{~g} \mathrm{dm}^{-3}$ for a content of $50.12 \mathrm{mg} \mathrm{cm}^{-2}$. In a study with Eugenia uniflora L., there was also a increase in the chlorophyll content due to the increase in the doses of Osmocote. The authors pointed out that the increased levels of chlorophyll contents in leaves contribute to a greater light absorption capacity of waves of different length from the peaks of photosynthesis (ELLI et al., 2013).

As for photosynthetic rate, there was an increase of the variable with increasing doses of Osmocote, with MTED estimated at $9.4 \mathrm{~g} \mathrm{dm}^{-3}$, which corresponds to a value $33 \%$ higher than the control treatment (Figure 2). According to Hikosaka (2004), the photosynthetic rate is related to the variation of the $\mathrm{N}$ content, since approximately $60 \%$ of the total nitrogen of the leaf is found in chloroplasts, mainly forming part of photosynthesis enzymes. 
Figure 2: Leaf area (LA), relative chlorophyll content (SPAD) and photosynthesis rate of Handroanthus heptaphyllus (Vell.) Mattos seedlings as a function of controlled release fertilizer (Osmocote) doses at 60 days after germination.
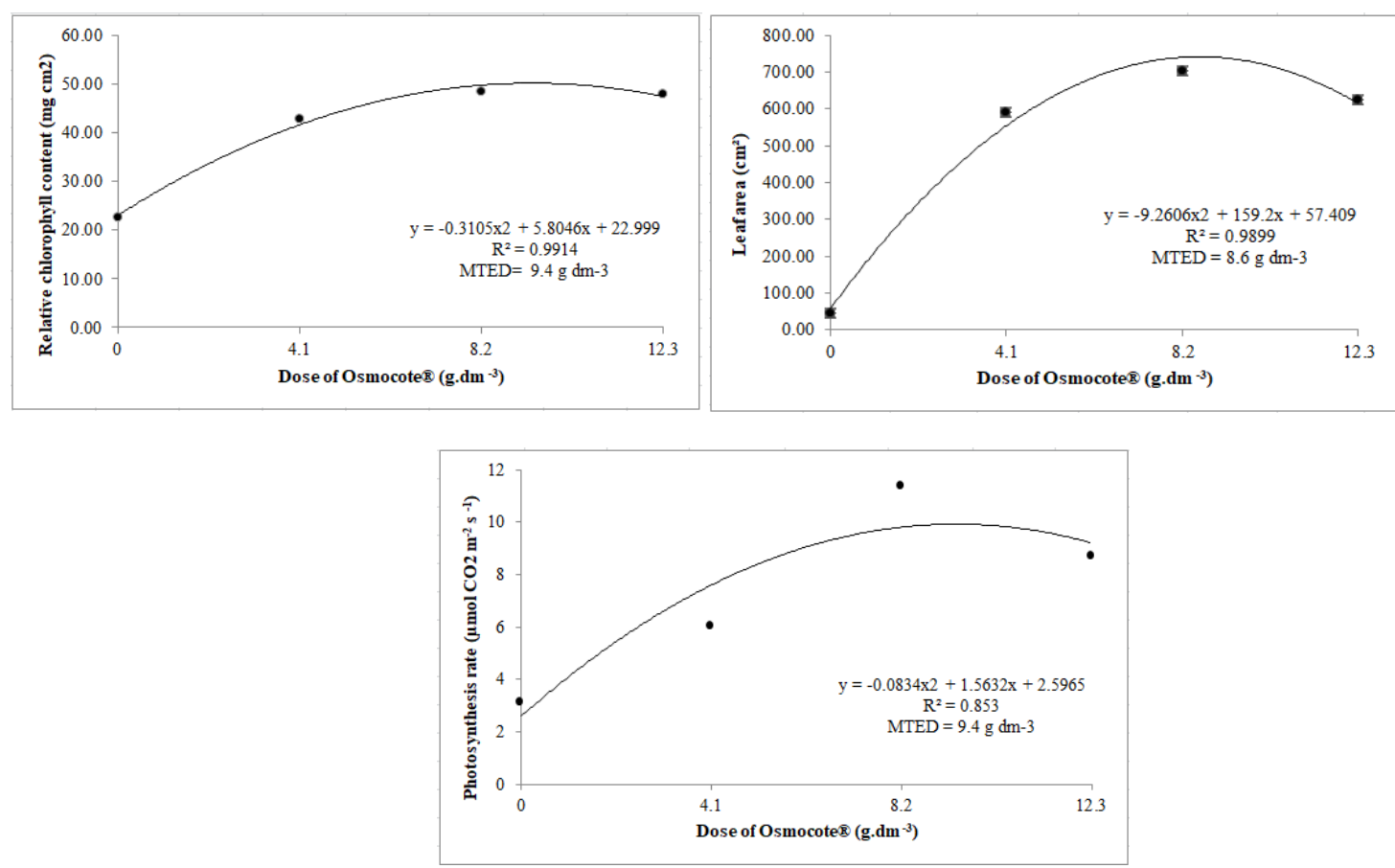

Source: Authors, 2019.

For the H/SD ratio (Figure 3), which relates two of the most used parameters for seedling quality, a similar behavior was observed, with MTED at $7.6 \mathrm{~g} \mathrm{dm}^{-3}$, representing an increase of 33\% when compared to the control treatment. According to Fonseca et al. (2002), to better determine the quality of the seedling, this variable must be analyzed together with the other studied parameters in order to determine the quality of seedling with greater precision. 
Figure 3: Relationship between height and stem diameter (H/SD), root dry mass (RDM), shoot dry mass (SDM), total dry mass (TDM); relationship between shoot dry mass and root dry mass (SDM/RDM) and Dickson's quality index (DQI) of Handroanthus heptaphyllus (Vell.) Mattos seedlings as a function of controlled release fertilizer (Osmocote ${ }^{\circ}$ ) doses at 60 days after germination.
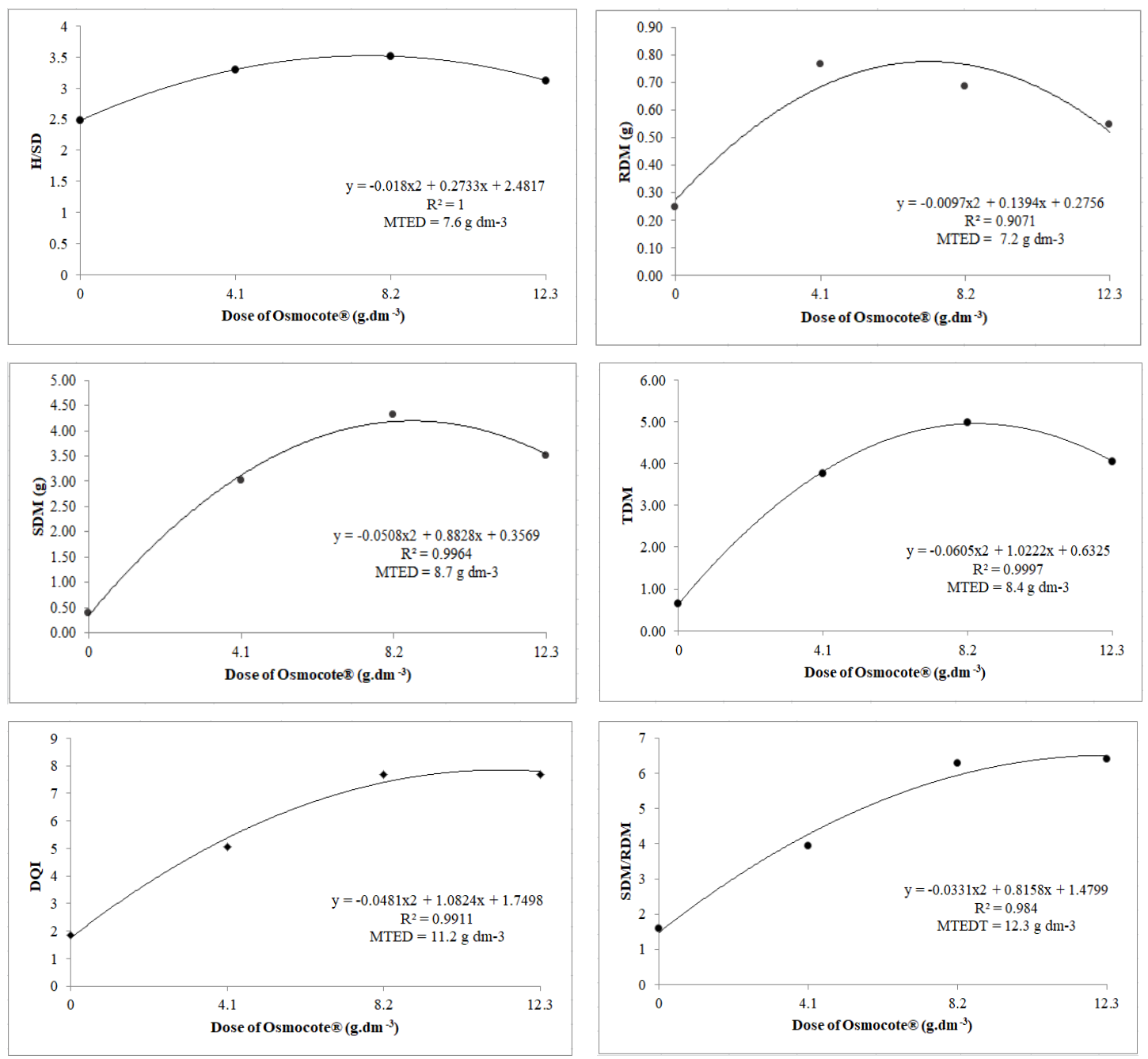

Source: Authors, 2019.

For the variable root dry mass (RDM), MTED was estimated at $7.2 \mathrm{~g} \mathrm{dm}^{-3}$ (Figure 3), which was $30 \%$ higher than the value obtained in the control treatment, which had an RDM of $0.25 \mathrm{~g}$. Therefore, doses higher than $7.2 \mathrm{~g} \mathrm{dm}^{-3}$ might impair root development, affecting water and nutrient absorption. A similar result was observed by Pezzutti et al. (1999), who evaluated the growth of seedlings of eucalyptus species (Eucalyptus globulus subsp. Maidenii) under conventional (60\%) and controlled-released (40\%) NPK fertilization. The authors 
concluded that the maximum growth of the dry mass of the root system was obtained in the dose range 6.7 to $7.5 \mathrm{~kg} \mathrm{dm}^{-3}$.

Rossa et al. (2015) showed similar results when analyzing the development of Anadenanthera peregrina (L.) Speg. and Schinus terebinthifolius Raddi. seedlings submitted to increasing doses of controlled -release fertilizers, with maximum values for RDM at MTED of $6 \mathrm{~kg} \mathrm{~m}^{-3}$ and $10 \mathrm{~kg} \mathrm{~m}^{-3}$, respectively.

For shoot dry mass, MTED was estimated at $8.7 \mathrm{~g} \mathrm{dm}^{-3}$ (Figure 3). This result was proportional to the value of leaf area, in which there was also an increase up to an intermediate dose of $8.6 \mathrm{~g} \mathrm{dm}^{-3}$. This variable is extremely important to analyze the quality of seedlings, since it directly influences how much the plant will develop, due to the increase in the photosynthetic rate and the absorption of water and nutrients by the root system (LISBOA, 2018).

Bachião et al. (2018), using the cultivar Catuaí 62 of Coffea arabica L. submitted to increasing doses of Osmocote ${ }^{\circ}$, found a MTED value of $10.9 \mathrm{~g} \mathrm{~L}^{-1}$ for RDM. In addition, the authors pointed out that increasing doses of CRF provided greater growth in Coffea arabica L. seedlings regardless of the studied cultivar.

For total dry mass, MTED was estimated at $8.44 \mathrm{~g} \mathrm{dm}^{-3}$ (Figure 3). Dutra (2016), who evaluated the growth and quality of Peltophorum dubium seedlings submitted to different doses of CRF, obtained similar results, with MTED value estimated at $8.2 \mathrm{~g} \mathrm{dm}^{-3}$.

The increase in the doses of Osmocote caused increases in the values of the SDM/RDM ratio, providing an improvement in the quality of the seedling, ensuring a better establishment of the seedlings prior to field cultivation. The value of MTED for the SDM/RDM ratio was $6.39 \mathrm{~g} \mathrm{dm}^{-3}$ (Figure 3). In a similar study with Delonix regia seedlings and Tecoma stans carried out with increasing dosages of Osmocote ${ }^{\circ}$, Massad et al. (2016) observed an increase in the SDM/RDM ratio, with MTED of $10 \mathrm{~g} \mathrm{dm}^{-3}$.

For the Dickson's quality index (Figure 3), there was a significant response to the increase in doses of Osmocote, with MTED estimated at $11.2 \mathrm{~g} \mathrm{dm}^{-3}$. The index is a good indicator of seedling quality, since it considers the robustness and balance of the distribution of biomass in the seedling, considering the results of several important parameters used in 
the quality assessment (FONSECA et al., 2002). Somavilla (2014) observed similar results, when evaluating the growth of Toona ciliata seedlings submitted to different doses of Osmocote ${ }^{\circ}$ The author obtained increasing values of DQI with the increase in the fertilizer doses.

\section{CONCLUSIONS}

The doses of the studied controlled release fertilizer positively influenced the seedling quality of Handroanthus heptaphyllus (Vell.) Mattos when produced with Tropstrato ${ }^{\circ}+$ vermiculite.

Considering the evaluated experimental conditions of the present study, doses of CRF Osmocote ${ }^{\circledR}$ (15-09-12) should range from 8.5 to $9.5 \mathrm{~g} \mathrm{dm}^{-3}$ for the production of Handroanthus heptaphyllus (Vell.) Mattos seedlings.

The use of the controlled-release fertilizer contributes effectively to reducing the production time of Handroanthus heptaphyllus (Vell.) Mattos seedlings in nurseries, increasing their resistance in the field.

\section{REFERENCES}

ALVES, F. J. B; FREIRE, A.L.O. Crescimento inicial e qualidade de mudas de ipê-roxo (Handroanthus impetiginosus (Mart. ex DC) Mattos) produzidas em diferentes substratos. ACSA, Patos-PB, v.13, n.3, p.195-202, Julho-Setembro, 2017, ISSN: 1808-6845.

BACHIÃO, P. O. B., de REZENDE MACIEL, A. L., AVILA, R. G., \& CAMPOS, C. N. Crescimento de mudas de cafeeiro em tubetes com fertilizante de liberação lenta. Revista Agrogeoambiental, v. 10, n. 1, 2018.

CARVALHO, P. E. R. Espécies Florestais Brasileiras: recomendações silviculturais, potencialidades e uso da madeira. Colombo: Embrapa. 1994. 640 p.

CECONI, D. E.; POLLETO, I.; LOVATO, T.; MUNIZ, M. F. B. Exigência nutricional de mudas de erva-mate (Ilex paraguariensis A. St.-Hil.) à adubação fosfatada. Ciência Florestal, Santa Maria, v. 17, n. 1, p. 25-32, 2007.

CRUZ, C. A. F.; PAIVA, H. N.; GUERRERO, C. R. A. Efeito da adubação nitrogenada na produção de mudas de setecascas (Samanea inopinata (Harms) Ducke). Revista Árvore, Viçosa, v. 30, n. 4, p. 537-546, 2006. http://dx.doi.org/10.1590/S010067622006000400006

DICKSON, A., LEAF, A. L., HOSNER, J. F. Qualitty appraisal of white spruce and white pine seedling stock in nurseries. Forestry Chronicle, v. 36, p. 10-13, 1960. 
DUTRA, T. R.; MASSAD, M. D.; SARMENTO, M. F. Q. Fertilizante de liberação lenta no crescimento e qualidade de mudas de canafístula (Peltophorum dubium). Floresta, v. 46, n. 4, p. 491-498, 2016. Disponível em: DOI: 10.5380/rf.v46i3.44570.

Elli, E. F., CANTARelli, E. B., CARON, B. O., MONTEiro, G. C., PAVAN, M. A., Pedrassani, M., \& ElOy, E. Osmocote $^{\circledast}$ no desenvolvimento e comportamento fisiológico de mudas de pitangueira. Comunicata Scientiae, Bom Jesus, v.4, n.4, p.377-384, Out./Dez. 2013. e-ISSN: 2177-5133.

FONSECA, É. D. P., VALÉRI, S. V., MIGLIORANZA, É., FONSECA, N. A. N., \& COUTO, L. Padrão de qualidade de mudas de Trema micrantha (L.) Blume, produzidas sob diferentes períodos de sombreamento. Revista árvore, p. 515523, 2002.

FREITAS, S. D. J., CARVAlHO, A. J. C. D., Berilli, S. D. S., SANTOS, P. C. D., \& MARINHO, C. S. Substratos e osmocote $^{\circledast}$ na nutrição e desenvolvimento de mudas micropropagadas de abacaxizeiro cv. Vitória. Rev. Bras.Frutic. Vol.33 no.spe1 Jaboticabal Oct. 2011.

GARCIA, E. A., SOUZA, J. P. Avaliação da qualidade de mudas de Schizolobium parahyba em função de diferentes aplicações de adubo fosfatado. Tekhne e Logos, Botucatu, v. 6, n. 1, p. 51-59, 2015.

GREGóRIO, T. A., GOBBO, L. G., CARDOSO, J. F., DEMUNER, V. G., \& HEBLING, S. A. Efeito do alagamento sobre o crescimento inicial de Tabebuia heptaphylla (Vell.) Toledo (Ipê-rosa). Natureza online 6 (2): 91-98. [on line] http://www.naturezaonline.com.br.

HIKOSAKA, K. Interspecific difference in the photosynthesis-nitrogen relationship: patterns, physiological causes, and ecological importance. Journal of Plant Research, v.117, n.6, p.481-494, 2004.

JOSÉ, A. C., DAVIDE, A. C., \& de OLIVEIRA, S. L. Efeito do volume do tubete, tipo e dosagem de adubo na produção de mudas de aroeira (Schinus terebinthifolia Raddi). Agrarian, v.2, n.3, jan./mar. 2009.

LisboA, A. C., de Melo, C. J. A. H., TAVARES, F. P. A., de AlmeidA, R. B., de MElO, L. A., \& MAGiSTRALI, I. C. Crescimento e qualidade de mudas de Handroanthus heptaphyllus em substrato com esterco bovino. Pesquisa Florestal Brasileira, v. 38, 2018.

MARQUES, L. S., PAIVA, H. N. D., NEVES, J. C. L., GOMES, J. M., \& SOUZA, P. H. D. Crescimento de mudas de jacaré (Piptadenia gonoacantha JF Macbr.) em diferentes tipos de solos e fontes e doses de nitrogênio. Revista Árvore, v. 33, n. 1, p. 81-92, 2009.

MASSAD, M. D., DUTRA, T. R., SILVA, C. H. S., SANTOS, T. B., \& SARMENTO, M. F. Q. Desenvolvimento de mudas de flamboyant e ipê-mirim em resposta a diferentes doses de Osmocote ${ }^{\circledR}$. Agropecuária científica no semiárido, v. 12, n. 1, p. 83-92, 2016.

MCCORMICK, A. J.; CRAMER, M. D.; WATT, D. A. Sink strength regulates photosynthesis in sugarcane. New Phytologist, Lancaster, v. 171, n. 4, p. 759-770, 2006.

MENDONÇA, V.; ARRUDA, N.A.A. ; SOUZA, H.A.; TEIXEIRA, G.A.; HAFLE, O.M.; RAMOS, J.D. Diferentes ambientes e Osmocote na produção de mudas de tamarindeiro (Tamarindus indica). Ciência e Agrotecnologia, Lavras, v.32

MENEGATTI, R. D., NAVROSKI, M. C., GUOLLO, K., FIOR, C. S., SOUZA, A. G., \& POSSENTI, J. C. Formação de mudas de guatambu em substrato com hidrogel e fertilizante de liberação controlada. Revista Espacios, v. 38, n. 22, p. 35-43, 2017.

MONTEIRO, J.E.B.A., SentelHA, P. C., ChiAVEGATO, E. J., GUiSElini, C., SANTiAGO, A. V. \& PRELA, A. 2005. Estimação da área foliar do algodoeiro por meio de dimensões e massa das folhas. Bragantia, 64(01): 15-24.

de FreitAs, T. P., BARRoso, D. G., LAMÔNICA, K. R., \& de CARVAlHO, G. C. M. W. Aplicação de AIB e tipo de miniestacas na produção de mudas de handroanthus heptaphyllus mattos. Ciência Florestal, Santa Maria, v. 26, n. 1, p. 313-320, jan.-mar., 2016 ISSN 0103-9954. 
PEZZUTTI, R. V.; SCHUMACHER, M. V.; HOPPE, J. M. Crescimento de mudas de Eucalyptus globulus em resposta à fertilização NPK. Ciência Florestal, v.9, n.2, p.117 -125, 1999.

de CASTRO PIAS, O. H., BERGHETTI, J., SOMAVILLA, L., \& CANTARELLI, E. B. Produção de mudas de cedro em função de tipos de recipiente e fontes de fertilizante. Pesq. flor. bras., Colombo, v. 35, n. 82, p. 153-158, abr./jun. 2014. doi: $10.4336 / 2014 . p f b .35 .82 .714$

ROSSA, Ü. B., ANGElO, A. C., WESTPHALEN, D. J., de OliVeirA, F. E. M., da SILVA, F. F., \& de ARAUjo, J. C. Fertilizante de liberação lenta no desenvolvimento de mudas de Anadenanthera peregrina (L.) Speg. (angicovermelho) e Schinus terebinthifolius Raddi (aroeira-vermelha). Ciência Florestal, v. 25, n. 4, p. 841-852, 2015. Disponível em: DOI: 10.5902/1980509820582.

ROSSA, U.B.; ANGELO, A.C.; NOGUEIRA, A.C.; REISSMANN, C.B.; GROSSI, F.; RAMOS, M.R. Fertilizante de liberação lenta no crescimento de mudas de araucaria angustifolia e ocotea odorífera. Floresta, v.41, n.1, p.491-500, 2011.

da SILVA, E. J. S, SENADO, J. A. V, da SILVA, Á. E., GAMA, M. A. P, OHASHI, S. T., de SOUZA, G. M. P., FERREIRA, G. C., NORONHA, N. C., de MATOS, G. S. B., de ARAUJO, D. G. Growth and Quality of Inga heterophylla Willd Seedlings According to the Slow Release Fertilizer. Journal of Agricultural Science; Vol. 11, No. 5; 2019 ISSN 1916-9752. E-ISSN 1916-9760. Published by Canadian Center of Science and Education.

SOMAVILLA, A., CANTARELLI, E. B., MARIANO, L. G., ORTIGARA, C., \& DA LUZ, F. B. Avaliações morfológicas de mudas de Cedro australiano submetidas a diferentes doses do fertilizante osmocote plus ${ }^{\oplus}$. Comunicata Scientiae, v. 5, n. 4, p. 493-498, 2014.

STÜPP, Â. M., NAVROSKI, M. C., FELIPPE, D., KNIESS, D. D. C., AMANCIO, J. C., SILVA, M. A., \& de OLIVEIRA PEREIRA, M. Crescimento de mudas de Mimosa scabrella Benth em função de diferentes tamanhos de recipientes e doses de fertilizante. Ecologia e Nutrição Florestal, v. 3, n. 2, p. 40-47, 2015. Disponível em: DOI: 10.5902/2316980X18613

WARING, R.H.; SCHLESINGER, W.H. 1983. Forest ecosystems and management. Academie Press, New York, 1983.340p.

ZAMITH, L.R.; SCARANO, F.R. Produção de mudas de espécies das Restingas do município do Rio de Janeiro, RJ, Brasil. Acta Botanica Brasilica, v.18, p.161-176, 2004.

\section{(c)) EY}

Este trabalho está licenciado com uma Licença Creative Commons - Atribuição 4.0 Internacional. 